\title{
Economics of waste management and disposal: decoupling, policy enforcement and spatial factors
}

\author{
Alessio D'Amato · Shunsuke Managi • \\ Massimiliano Mazzanti
}

Published online: 4 October 2012

(C) Springer 2012

Waste production is increasing steadily over time in developed as well as in developing countries. The growth is still more or less proportional to that of GDP for most countries and regions. The evidence also suggests that a significant amount of waste is produced each year in OECD countries (over 4 billion tonnes). ${ }^{1}$ In the EU, waste-related Directives, such as 2008/98/CE, now call for waste reduction as the most preferred option to tackle this problem, while in the past attention was mainly focused on recycling, recovery and disposal targets. Also, as suggested by the European Commission, ${ }^{2}$ economic growth and globalization are boosting waste movements across borders, involving potentially hazardous wastes. National and international institutions are reacting with mixed effectiveness to these issues, while the theoretical and empirical literature has developed substantially in recent years. Theoretical analyses have, for example, suggested designs of optimal policy packages in first and second best situations, holding attention to non-competitive

\footnotetext{
1 More than 2 thousand times the weight of Twin Towers overall recovered materials. Look at OECD's Work on Sustainable Materials \& Waste Management, March 2011, available at: http://www.oecd.org/ dataoecd/44/61/49136679.pdf (accessed 19/07/12).

2 See http://ec.europa.eu/environment/waste/shipments/index.htm (accessed 25/06/12).
}

\section{A. D'Amato $(\bowtie)$}

Department of Economics and Finance, Università di Roma Tor Vergata,

Via Columbia 2, 00133 Rome, Italy

e-mail: damato@economia.uniroma2.it

\section{S. Managi}

Graduate School of Environmental Studies, Tohoku University, 6-6-20 Aramaki-Aza Aoba, Aoba-Ku, Sendai 980-8579, Japan

e-mail: managi@mail.kankyo.tohoku.ac.jp

M. Mazzanti

Dipartimento di Economia Istituzioni Territorio, Università di Ferrara,

Via Voltapaletto 11, Ferrara 44100, Italy

e-mail: massimiliano.mazzanti@unife.it 
market scenarios, illegal market rents (see, among others, Shinkuma 2003; Shinkuma and Managi 2012) and dynamic issues. The increasing scarcity of land in most countries and the parallel increasing of urbanization worldwide have brought about the strengthening of policy targets on waste disposal, recovery and then on waste generation. The related increase in complexity must be addressed in a setting that accounts for the economic and institutional factors, through empirical analyses that provide evidence on policy effectiveness, relevance of specific regional features, impact of a comprehensive set of socio-economic drivers (Mazzanti and Montini 2009), as well as on the determinants and environmental consequences of waste-related trade (Kellenberg 2012).

The main aim of this special issue is to address waste management, trade and disposal, with both theoretical and empirical lenses, adding a strong policy-oriented flavour. To this end, several "real life" problems are investigated, and relevant policy implications are drawn out, including:

- Waste management efficiency measurement and evaluation;

- Waste trade determinants and impact on environmental quality;

- Waste policy in the presence of illegal disposal and enforcement problems;

- "New" waste management practices and linkages with other environmental issues.

Under the first respect, the paper by Nakano and Managi (2012) explores, using a Data Envelopment Analysis framework, the efficiency of Japanese prefectures explicitly incorporating waste generation. Inefficiencies are shown to arise in several prefectures, and the reduction in waste generation to fill the gap is estimated, providing an example of how such methodologies can be of practical policy relevance.

Two papers address the important issue of waste-related trade. The paper by D'Amato et al. (2012) focuses on the second hand market of plastic materials, developing a theoretical model and then testing its conclusions using polyethylene waste trade data. Somewhat surprisingly, the authors show how "common sense" conclusions do not necessarily hold in waste-related markets, as, for example, prices do not seem to play an important role. Complex interactions arise, on the other hand, among waste management, enforcement and export patterns. Another paper by Sugeta and Shinkuma (2012) is instead devoted to the analysis of environmental consequences of recycled materials trade in a realistic vertically structured model. As it emerges, the degree of heterogeneity in the recovery rates among countries is crucial for trade liberalization to be good or bad for environmental quality, showing that no one size fits all conclusion holds.

A policy relevant contribution is the empirical study performed by Nicolli (2012) with reference to municipal solid waste (MSW) related indicators in Italy. The author brings good news, insofar as he is showing that separated waste collection has converged across Italian provinces, while more pessimistic evidence relates to landfilling and incineration. Environmental policies, on one hand, and social polarization and organized crime, on the other, also matter, influencing the choices in terms of waste management. 
The paper by Bosello et al. (2012), using a computable general equilibrium model, addresses the possible role of waste incineration with energy recovery and controlled landfill biogas in contributing to $\mathrm{CO}_{2}$ mitigation. Focusing again on Italy, the authors emphasize the potentially significant cost savings that the waste-related options under scrutiny could bring, on the way towards the achievement of Italy's emission reduction target within the EU.

Evaluation of reusable product markets is also key in understanding waste policy. Especially in the EU, refilled reusable products are widespread, while other countries are still lagging behind. Numata and Managi (2012) provide evidence and an evaluation of the needed steps to improve the diffusion of reusable containers in Japan.

The route towards reduction of waste generation and increase in reuse of waste materials is one of the most challenging for environmental policy. If real life scenarios, accounting for illegal disposal, trade-related issues and complementarities with other environmental problems are properly considered in environmental economics and policy studies, relevant food for thought can be delivered to waste managers and policy makers to increase social welfare. We hope to have moved a first step in this direction.

\section{References}

Bosello F, Campagnolo L, Eboli F, Parrado R (2012) Energy from waste: generation potential and mitigation opportunity. Environ Econ Policy Stud. doi:10.1007/s10018-012-0043-5

D'Amato A, Iozzi A, Trovato G (2012) The trade of polyethylene waste: prices or policies? Environ Econ Policy Stud. doi:10.1007/s10018-012-0044-4

Kellenberg D (2012) Trading wastes. J Environ Econ Manag 64:68-87

Mazzanti M, Montini A (2009) Waste and environmental policy. Routledge, London

Nakano M, Managi S (2012) Waste generations and efficiency measures in Japan. Environ Econ Policy Stud. doi:10.1007/s10018-012-0038-2

Nicolli F (2012) Convergence of waste-related indicators of environmental quality in Italy. Environ Econ Policy Stud. doi:10.1007/s10018-012-0042-6

Numata D, Managi S (2012) Demand for refilled reusable products. Environ Econ Policy Stud. doi: $10.1007 / \mathrm{s} 10018-012-0037-3$

Shinkuma T (2003) On the second-best policy of household's waste recycling. Environ Resource Econ 24:77-95

Shinkuma T, Managi S (2012) Effectiveness of policy against illegal disposal of waste. Environ Econ Policy Stud 14:123-145

Sugeta H, Shinkuma T (2012) International trade in recycled materials in vertically related markets. Environ Econ Policy Stud. doi:10.1007/s10018-012-0036-4 